\title{
On Modern Computer Assisted Language Learning Facilities and its Integrated Teaching
}

\author{
https://doi.org/10.3991/ijet.v13i11.8542 \\ Yucheng Bai \\ Zhengzhou Railway Vocational \& Technical College, Henan, China \\ baiyucheng_byc@163.com
}

\begin{abstract}
The teaching model of Computer Assisted Language Learning Facilities and its integrated teaching has become the new model on the reform of college English Teaching in China. Its invention and implementation provides a powerful cognitive tool for comprehensive quality improvement in listening, speaking, reading and writing in English. This paper focuses on how to make full use of the advantages of multimedia and network, and explore Computer Assisted Language Learning and teaching model of English major curriculum integration. At the same time, this study brings the method of concrete implementation of facilities and issues that need to be paid attention to in English major teaching.
\end{abstract}

Keywords-Computer Assisted Language Learning facilities, English major teaching, network multimedia technology

\section{Introduction}

Computer Assisted Language Learning facilities can be traced back to the 1950s. The first computer assisted teaching system in human history was IBM650 which was from IBM research center to teach elementary school students the binary arithmetic. In the following decades, with the continuous development of computer software and hardware technology, especially the mature network multimedia technology, computer was gradually applied to auxiliary teaching of language in the 1980s to 1990s, which showed wide application prospects in the field. In the 21st century, Computer Assisted Language Learning facilities accelerated increasing of research interest for people from many aspects, and the related curriculum design, teaching evaluation, technology application, research theory and method of the article quantity were also increasing.

At present, due to the non-comprehensive recognition and understanding of the facilities, and many college foreign language education staff incline towards two extremes, when evaluating the nature and characteristics of it: firstly, part of the teachers support it with diversified function, powerful interactive features, nonlinear network structure, open learning environment, good instructive effect, it was a "magic weapon", and should be developed into a popular foreign language teaching methods; secondly, another part of the teachers were concerned about the excessive usage and relying on computer, and gradually losing the control of class atmosphere and initiative, eventu- 
ally leading to teaching staff being replaced by a machine. They argued that the application of new media posed a threat to their right to academic autonomy, and the more comprehensive application of education technology, the greater the surprise [1]. These staff were less willing to use the facilities, or because they were unfamiliar with computer operation, they could not deliver electronically supported lectures, or simply refused to use any courseware.

\section{Basic Concepts and Theoretical Basis}

Computer Assisted Language Teaching is a branch of Computer Assisted Learning. The term appeared around the 1980s. However, since the computer may play a major role in language teaching process, this had become a common term for Computer Assisted Language Teaching which required the computer to become the main media. Through the computer interaction between the students and computers is facilitated, and the supplement of conventional class teaching to teach students the language knowledge, and train language skills, in order to improve language teaching [2].

Integration is a process to design the various elements of curriculum management and is successfully used in Computer Assisted Language Learning classes. It is reported that integration can be divided into horizontal integration and vertical integration The former refers to the Computer Assisted Language Learning and school wider integration of technology infrastructure, such as the special hardware and software to be configured according to the school, and provide the necessary technical support and network resources. The latter refers to the Computer Assisted Language Learning and teaching integration technology education outside the classroom, learning other curriculum in campus or at home by computer.

At home and abroad, throughout the developed Computer Assisted Language Learning facilities and curriculum integration, current condition of teaching English as a foreign language in China requires new English course standard. A large number of experts expounds the current situation of English teaching as time-consuming and of low effectiveness, and relying on Information Technology, especially multimedia technology with computer. Therefore, modern Computer Assisted Language Learning facilities with college English teaching reform is the only method to integrate English teaching education. Starting in the 1990s, constructivism teaching thoughts gradually became a basis for theory of new generation of Computer Assisted Teaching. The basic idea was that knowledge was not obtained through teachers, but learners obtained with the others' assistance and necessary learning materials, through active construction of meaning [3].

The studies on cognitive psychology have shown that out of the same knowledge content, people could remember $10 \%$ information of what they read, $20 \%$ information of what they listened, 30\% information of what they observed. Whereas if they do it by themselves they could remember $90 \%$ of the information [4]. Multimedia education software has the characteristics of mutual communication between the human and the machine. With advantage of intuitive images, interesting, following psychological char- 
acteristics of the youth, is easy to understand and accept, and cultivate students' exploring spirit and creative ability. During the learning process, students could learn independently without restriction of time, space and teaching schedule. Therefore, in the information era, education teaching should carry out the educational reform experiment, promote the potential learning development and quality-oriented education, and cultivate students' innovation spirit and practice ability. Under the guidance of systematic scientific theory and teaching and learning theory, especially the teaching system design theory and mixed learning theory, the core technology of multimedia computer and communication network promoted students' autonomous learning, inquiry learning, collaborative learning, cognitive learning, assessment learning, feedback learning, innovation and emotional incentive learning.

Thus, the integration of computer assisted language learning facilities in teaching of English was helpful for students to obtain the rich perceptual materials, which was in accordance with epistemology, from perceptual knowledge to rational knowledge. The alternate application of variety of media mobilized the collaborative activities, such as various senses of seeing and learning, it could achieve the best learning effect, conforming to the theory of physiology. Rich learning resources of multimedia forms and a variety of communication methods were helpful to promote students' autonomous learning, inquiry learning and collaborative learning [5].

\section{Specific Patterns and Advantages and Disadvantages}

Modern Computer Assisted Language Learning facilities and foreign language curriculum and integration of specific model became instructional strategies, reflected the interaction of the use of computers for teaching activities. Teaching content and teaching methods directly affected the Computer Assisted Language Teaching model. According to the teaching content, computer language learning model usually had a common teaching of foreign language teaching and drill teaching model [4]; and from teaching methods, it could be divided into classroom teaching model, students self-study model, and network model.

\subsection{English Question Bank Construction}

The purpose of college English teaching is to cultivate students' ability in listening, speaking, reading and writing, thus providing a basis for further study and to use English practically. However, from the perspective of the current college English learning, test is still the main method. Therefore, English major courses must have a large, complete, scientific, standard, specification of operational problem sets and examinations of English question bank system, so as to test and practice the skills effectively. Based on the test, the teachers prepare a lesson in topic selection, it could be easily extracted from the question bank, problem sets. The problems in exam could be solved through the collected and sorted problem sets, analysis and comparison. 


\subsection{The Teaching Course Ware Designed}

During the use of computer assisted English lessons, the whole process of lessons design could be divided into two categories: library and dictionary with English word definition, grammar, text. There is another special library, which includes specific teaching activities. Namely, teaching goal analysis, teaching strategy analysis, teaching evaluation, library, teaching plan reference, and teaching database library. Teaching analysis was proposed to solve the problem of what should be taught through the teaching material analysis, teaching evaluation was proposed to solve the problems of teaching and learning effect though class exercises and homework, and could be the reference for experienced teachers prepare creative lesson plans. Reference lesson plan provide material through experienced teachers to write creative lesson plans. The database should focus on teaching course and providing various teaching information, teaching experience and directory, The computer could process all of daily accumulation, information about English teaching.

\subsection{Online Test}

Today, the use of computer organization English test can be done by two methods, one is to use paper to match the computer exam system, use relevant software to analyze relevant statistics rapidly, then print it out. Second, under the environment of electronic classroom or multimedia network classroom, the students fill in the answer on a computer terminal, the results on the final summary could go to teachers, which could be immediately displayed on the screen, and also through the computer Internet functions so that the feedback is given immediately to students. Each quantitative analysis could make teachers understand and assess the students and accurately, so that the students can correctly understand it immediately, in order to focus on targeted teaching and learning. This is especially conducive to English teaching, because the English tests had more choices. Using the computer multimedia network English teaching the answer can be given on the machine and get feedback from the computer screen immediately for other types of topic, students also can get timely information from the screen, analysis, information such as help and answer. Using a computer, the teacher can give individual lessons for all the students at the same time, help each student to practice, so that the students do not have any psychological pressure, and can see students' problem solving process in classroom by counseling.

Modern computer assisted language learning facilities with the advantages of the foreign language curriculum integration can be illustrated from two aspects. First, the successful application depend on the teacher's ability and ideas and depend on the teacher's active role.

Second, it is the characteristics of education: teaching material, self-independence of globalization, personalized teaching and learning resources, activities, management automation of cooperatives, virtualized environment, and open system. Computeraided language teaching is not universal, it also has disadvantages. 
Third, in the design of learning materials and teaching tasks one cannot satisfy all the learners and the learning situation of the key factors such as the learner's background, needs, goals, and technology and the school environment.

Fourth, in the practical training of foreign language teaching, especially writing and speaking skills also appear to be less effective. The multimedia teaching in teachers, learners and school carry out how to effectively integrate and find a practical and effective method.

\section{$4 \quad$ Integration principles}

Curriculum integration mainly refers to the course of learning activities in the combination of the use of Information Technology, in order to better complete the course objectives. However, the integration is not easy to be made. The key to English teaching integration is how to effectively apply the advantages of Information Technology to have a better English teaching goal, to cultivate the students' innovation spirit and practice ability. Through the Information Technology and English course in the curriculum content, curriculum resources, the implementation of the curriculum structure and curriculum could improve the English course teaching skills and the quality of curriculum and the realization of the aim of comprehensive education teaching reform. The integration principles as seen in Table 1.

Table 1. Basic principles in the integration

\begin{tabular}{|l|l|}
\hline \multirow{4}{*}{ Integration Principle } & 1. Autonomy Principle \\
\cline { 2 - 2 } & 2. Induced Principle \\
\cline { 2 - 2 } & 3. Integrity Principle \\
\cline { 2 - 2 } & 4. Aptitude Principle \\
\hline
\end{tabular}

\subsection{Autonomy Principle}

The goal of quality education require students not only to learn knowledge, but also to learn and master the methods and develop capacity. Therefore, in the process of Information Technology and English curriculum integration, with the students' independent inquiry learning as the focus, students are encouraged to deliberate and apply information technology to obtain information, to solve practical problems, to cultivate their innovation spirit and practice ability.

\subsection{Induced Principle}

The key to the success of English teaching is to stimulate students' learning interest and learning motivation. Therefore, the teacher must be good at using Information Technology to provide teaching resources, create the teaching situation that interest students, and induce their interest in learning, so that students have a relaxed and harmonious environment of English learning. 


\subsection{Integrity Principle}

Information Technology contains English subject curriculum content, curriculum resources, the implementation of curriculum structure and curriculum, and bring the teaching idea, teaching mode, teaching method and comprehensive innovation. It should effectively use Information Technology to obtain the information resources, and become a new kind of learning mode. Therefore, it is pivotal to hold the English integration idea and macro learning view, instead of taking Information Technology simply as a tool of teaching.

\subsection{Aptitude Principle}

Psychology and the theory of multiple intelligence prove that personality and intelligence are different, only according to their aptitude, students can truly achieve geared to the needs of all students, fully promote students' all-round development and personality development (Kong et al, 2003). In the information technology and curriculum integration in the process of middle school English teaching, teachers should be focused on the differences of students' quality and ability to set different learning content and learning goals.

\section{The Consideration and Suggestion of Integration}

Modern Computer Assisted Language Learning facilities and the development trend of English curriculum integration are to cultivate students' information literacy; Communication and cooperation in daily life highlights the information acquisition, processing, management and expression of ideas . Information Technology applied to English teaching and learning resources, can make the students learn effectively [7]. The teacher in the process of integration of information technology and English teaching, need to think from the following several aspects:

Firstly, foreign language courses pay attention to the research of teaching methods and teaching integration. The choice of teaching methods, the teacher should first consider the teaching content and teaching goals and student's actual situation, select the most appropriate method to accomplish the teaching contents. At the same time, it cannot completely avoid the traditional classroom teaching mode. The information technology and traditional teaching method is a kind of auxiliary teaching means and teachers cannot rely solely on the information technology to improve the quality of English teaching, the traditional teaching materials (such as blackboard, chalk, wall charts etc.) are worth using.

Secondly, it cannot ignore the facilities provided to teachers to achieve optimization of Computer Assisted Language Teaching, it need three conditions: hardware, software and human ware. Human ware construction, mainly refers to the teachers' training is most difficult, because teachers' participation is the decisive factors in any education technology.

It is a pivotal era for the integration of professional course teaching with foreign language. In the beginning, all people involved should stay calm and consider seriously 
about its positioning problem, enhance the consciousness, promote healthy development. It should widely absorb the successful experience at home and abroad to establish a base on the theory of language learning, and adopt computer assisted language learning facilities.

\section{Acknowledgment}

This study was supported by Henan Province Society Scientific Circles Federation (Project Number: SKL-2015-1657) and Teaching and scientific research projects of Zhengzhou Railway Vocational \&Technical College (Project Number: 2015JKY032).

\section{$7 \quad$ References}

[1] Cai, J. G. (2003). Foreign Language Ability and Foreign Language Policy in China. Foreign Languages and Their Teaching, (3):155-162.

[2] Chen, J. L. (2003). Introduction on Modern Distance Education. Beijing: Science Press, 2003.

[3] Gu, J. X. Computer-assisted Language Teaching. Wuhan: Press for Huazhong University of Science and technology, 2000.

[4] Gu, Z. Z., Chen, J. L. On Modern CALL Research and Language Teaching and Review on Problems and Countermeasures Study of Computer Assisted Language Learning. Foreign Language World, 2009.

[5] He, K. K. Constructivism: the Innovation of Traditional Teaching Theories. Electro-chemical Education Research, 1997.

[6] Kong, Q. Y., Hu, Z. L., Gui, S. C., et al. Focus on University Experience English, China University Teaching, 2003.

[7] Zhang, Y., Yan, G. F. The Main Factors Restricting the Development of Network Education in America. Comparative Education Review, 2001.

\section{$8 \quad$ Author}

Yucheng Bai is with the Zhengzhou Railway Vocational \& Technical College, Henan, 450052, China (baiyucheng_byc@163.com)

Article submitted 07 March 2018. Resubmitted 19 July and 12 August 2018. Final acceptance 13 August 2018. Final version published as submitted by the author. 